\title{
PERAN PONDOK PESANTREN SUNAN DRAJAT DALAM PEMBERDAYAAN EKONOMI
}

\author{
Maulia Rahmatika \\ Departemen Ekonomi Syariah-Fakultas Ekonomi dan Bisnis-Universitas Airlangga \\ Email: mauliarahmatika@gmail.com \\ Sunan Fanani \\ Departemen Ekonomi Syariah-Fakultas Ekonomi dan Bisnis-Universitas Airlangga \\ Email: sunanfanani@gmail.com
}

\begin{abstract}
:
Pesantren are Islamic educational institutions that participate in the empowerment of the community's economy through their efforts. One of the pesantren famous for its wealth is Pesantren Sunan Drajat Lamongan, East Java. The purpose of this study was to knowing about the role of Pesantren Sunan Drajat in economic empowerment. The research method was descriptive qualitative with case study design. The research data collected by interview, direct observation, and documentation. The collected data is validated by means of source and technique triangulation. The role of economic empowerment built in this study refers to the CIPP evaluation model. Based on the results of the analysis show that the economic empowerment of the PesantrenSunanDrajat which is renewed through CIPP approved to be able to educate the students' mentality and expertise, and improve the standart living of society. There are also pesantren activities that lead to indirect empowerment, which can help the economic welfare of santri and the society.
\end{abstract}

Keyword: Economic Empowerment, Pesantren, CIPP Evaluation Model.

I. PENDAHULUAN

Bentuk pemberdayaan yang dilakukan oleh pesantren dapat dilihat dari berbagai sudut pandang, yakni pendidikan, agama, dan sosial keagamaan, termasuk ekonomi. Pengelompokan ini disebabkan oleh latar belakang pesantren yang berdiri dari dan untuk masyarakat dengan tujuan mentransformasikan keadaan masyarakat mulai dari urusan ibadah hingga urusan muamalah.

$$
\text { Faktor yang melatarbelakangi }
$$
adanya fungsi pemberdayaan adalah mayoritas santri yang mengaji di pesantren berasal dari masyarakat kurang mampu, sehingga agar tidak menghalangi misi penyebaran dakwah, pembelajaran di pesantren tidak memungut biaya. Santri dapat memenuhi kebutuhannya sendiri dengan bekerja pada usaha milik kiai, milik pesantren, atau milik masyarakat sekitar. Adapun pemenuhan kebutuhan operasional pesantren berasal dari zakat, infaq, shadaqah, atau wakaf orang-orang sholeh (Geertz, 2014: 256).

Pada tahun 1990-an, terdapat transformasi pengelolaan pesantren di Indonesia sebab terdapat perubahan sistem pendidikan yang mulai kooperatif terhadap perkembangan kemajuan ilmu pengetahuan dan teknologi (Fauroni, 2011: 10). Beberapa pesantren mulai mengenakan biaya pendidikan sesuai tingkatan sekolah dan mulai

\footnotetext{
${ }^{1}$ Jurnal ini adalah bagian dari skrispi Maulia Rahmatika, NIM: 041311433112 , yang diuji pada tanggal 16 Juli 2019.
} 
Rahmatika, et al/Jurnal Ekonomi Syariah Teori dan Terapan Vol. 6 No. 10 Oktober 2019: 2052-2061; PERAN PONDOK PESANTREN SUNAN DRAJAT DALAM PEMBERDAYAAN EKONOMI

memfokuskan diri dalam hal pembelajaran santri, dan tidak berperan dalam pemberdayaan ekonomi masyarakat (Jamaluddin, 2012: 134).

Namun hal tersebut tidak serta merta menunjukkan bahwa setiap pesantren telah kehilangan identitasnya sebagai lembaga pemberdaya ekonomi masyarakat. Tim Pekapontren dalam Fauroni (2011: 3) menyebutkan bahwa pada tahun 2004, dari 14.798 pesantren di Indonesia terdapat 1.529 pesantren yang mengembangkan usaha di bidang pertanian dan agribisnis, 404 di bidang perindustrian, 111 di bidang perdagangan, dan 41 di bidang ekonomi kelautan dan perikanan. Hal ini menunjukkan bahwa masih ada pesantren yang berperan di bidang pemberdayaan ekonomi masyarakat.

Mursyid (2011: 176) menyatakan bahwa pada umumnya usaha pesantren masih sangat sederhana dan belum terorganisir dengan baik, terlebih jumlah pesantren yang berperan dalam pemberdayaan ekonomi masyarakat belum mencapai 50\%. Namun terdapat sebuah pesantren yang telah dikenal baik aspek kewirausahaannya yakni Pondok Pesantren Sunan Drajat (PPSD) di Lamongan. Pesantren tersebut memiliki beragam unit usaha, baik di bidang agribisnis, manufaktur, maupun bidang perdagangan/jasa. Dari usaha-usaha tersebut, PPSD dapat membuka lapangan kerja bagi santri dan masyarakat sekitar, memberikan penggratisan dan fasilitas pada ratusan santri karyawan (santri yang mengaji di pesantren sambil membangun pesantren), memberikan keringanan biaya pendidikan pada santri, melakukan pembangunan fasilitas pesantren secara mandiri setiap tahun, dan sebagainya (Ahwarumi, 2011: 104).

Mengingat bahwa tidak semua pesantren berperan dalam pemberdayaan ekonomi masyarakat, pengetahuan mengenai bentuk pemberdayaan yang diterapkan oleh PPSD penting untuk diketahui agar dapat dijadikan sebagai referensi atau teladan bagi pesantren lainnya. Oleh sebab itu, rumusan masalah dalam penelitian ini adalah bagaimana peran Pondok Pesantren Sunan Drajat dalam pemberdayaan ekonomi. Penelitian ini bertujuan untuk mengetahui secara mendalam dan mendeskripsikan bentuk pemberdayaan ekonomi yang ada di pesantren tersebut.

\section{LANDASAN TEORI}

Definisi pemberdayaan ekonomi dalam satu frasa adalah upaya membantu masyarakat untuk meningkatkan kemampuannya dalam menciptakan wirausaha baru, peningkatan akses pada aset produksi, memperkuat posisi transaksi dan kemitraan usaha dengan cara berpartisipasi aktif dalam proses pengambilan keputusan dan dalam menentukan pilihan masa depannya (Muslim, 2014: 16). 
Proses yang harus dilalui dalam suatu pemberdayaan minimal terdiri dari tiga hal, yakni penyadaran, pengkapasitasan, dan pendayaan. Pertama, penyadaran, pada tahap ini sasaran pemberdayaan diberi suatu pencerahan atau motivasi agar mereka sadar bahwa mereka berhak untuk memiliki sesuatu dan sadar akan permasalahan yang dihadapi. Kedua, pengkapasitasan, adalah proses belajar tentang pengetahuan dan kecakapan keterampilan yang relevan dengan kebutuhan masyarakat. Ketiga, pemberian daya, pada tahap ini masyarakat diberikan daya, kekuasaan, otoritas, atau peluang untuk melakukan sesuatu sesuai dengan kecakapan masyarakat (Dwidjowijoto dan Wrihatnolo, 2007: 30-33).

Tujuan dari rangkaian proses pemberdayaan ekonomi tersebut adalah mewujudkan masyarakat yang mandiri dan stabil secara finansial. Oleh sebab itu, hasil dari pemberdayaan ekonomi masyarakat hendaknya berakhir pada terwujudnya empat bidang (Mardikanto, 2010: 75-86), yakni:

1. Bidang Bina Manusia, merupakan upaya penguatan/pengembangan kapasitas individu.

2. Bidang Bina Usaha. Bentuknya dapat berupa peningkatan keterampilan usaha, pengelolaan bisnis usaha kecil, pemudahan akses modal, dan sebagainya.
3. Bidang Bina Lingkungan. Bentuknya dapat berupa lingkungan fisik maupun nonfisik yang dapat mempengaruhi keberlanjutan keberdayaan masyarakat.

4. Bidang Bina Kelembagaan. Efektifitasnya kelembagaan dapat berupa pembangunan kemitraan mutualistik antar pelaku ekonomi rakyat, penyediaan peraturan atau perundang-undangan mengenai pemberdayaan atau pengentasan kemiskinan, dan sebagainya.

Pesantren merupakan salah satu tipe lembaga keagamaan yang memberdayakan ekonomi masyarakat di Indonesia. Tipe lainnya adalah organisasi filantropi Islam yang memberikan layanan sosial kepada korban bencana alam dan masyarakat miskin (Sakai and Isbah, 2014: 722). Oleh sebab itu, penanaman ideologi mengenai etos kerja dan pengajaran berekonomi secara Islam baik secara lisan maupun tindakan, merupakan tanggung jawab pesantren yang berperan sebagai lembaga dakwah dan lembaga pemberdaya masyarakat.

Pada dasarnya kronologi munculnya usaha ekonomi pesantren dimulai dari pemenuhan kebutuhan pesantren untuk menghidupi dirinya (survive). Kemudian dengan dimotivasi oleh nilai ilaihi dan insani atau tanggung jawab secara vertikal dan horisontal, pesantren mengembangkan perannya sebagai bentuk pengabdian masyarakat (Siswanto NS, 2008: 29). 
Kudhori (2013: 21-23) menyebutkan ayat-ayat Al-Quran yang perlu dijadikan prinsip dalam pemberdayaan ekonomi masyarakat adalah pertama, berlindung kepada Allah karena ancaman-Nya terhadap para pendusta agama sebagaimana tertera dalam QS. AI Ma'un (107) ayat 1-7. Kedua, karena harapan pada janji Allah yang diperuntukkan bagi orang yang membantu atau memberdayakan orang lain seperti dalam QS. Al Baqarah (2) ayat 261-262.

Untuk menjabarkan peran pemberdayaan PPSD, penelitian ini menggunakan kerangka analisa model evaluasi CIPP yang bersifat sumatif sehingga temuan dapat menginformasikan kepada khalayak umum mengenai apa yang direncanakan, dicoba, dilakukan, dan dicapai PPSD dalam hal pemberdayaan ekonomi. Penyelesaian laporan sumatif, mengacu pada informasi context, input, process, product dan informasi tambahan yang dibutuhkan.

\section{METODE PENELITIAN}

Penelitian ini menggunakan pendekatan kualitatif deskriptif. Tujuannya adalah agar dapat mendeskripsikan dan menggambarkan fakta, sifat, dan hubungan antar fenomena dalam pemberdayaan ekonomi Pondok Pesantren Sunan Drajat (PPSD) secara sistematis, faktual, dan akurat.

Penelitian ini menggunakan data primer dan sekunder. Data primer berupa wawancara pada pihak pemberdaya dan sasaran pemberdayaan di Pondok Pesantren Sunan Drajat. Data sekunder berupa observasi langsung dan dokumentasi. Keabsahan data di uji melalui teknik triangulasi sumber dan triangulasi teknik.

Teknik analisis yang digunakan dalam penelitian ini mengikuti model Miles dan Huberman yang terdiri dari pengumpulan data, reduksi data, penyajian, penarikan Kesimpulan (Sugiyono, 2015: 246-253)

\section{HASIL DAN PEMBAHASAN}

PPSD berdiri secara resmi pada tanggal 7 September 1977 di wilayah pantura Pulau Jawa tepatnya di Jl. Raden Qosim, Kec. Banjaranyar, Kab. Paciran, Kota Lamongan. PPSD didirikan oleh Prof. Dr. (H.C.) K. H. Abdul Ghofur dan bercikal bakal dari pesantren yang didirikan oleh Raden Qosim (SunanDrajat) pada waktu \pm 500 tahun silam. Oleh sebab itu, pesantren ini memiliki keterikatan secara geografis, psikologis, filosofis, dan historis dengan Sunan Drajat.

Pada saat ini, PPSD telah mencetak alumni santri yang berjumlah ribuan. Adapun yang masih berstatus sebagai santri dan tercatat dalam administratif pesantren berjumlah 7.499 jiwa dengan rincian sebagai berikut:

Tabel 1.

Jumlah Santri PPSD Tahun Pelajaran 2016/2017

\begin{tabular}{|l|l|}
\hline Santri Berdasarkan Jenis Kelamin & Jumlah \\
\hline Santri Putra & 4.341 \\
\hline Santri Putri & 3.158 \\
\hline
\end{tabular}




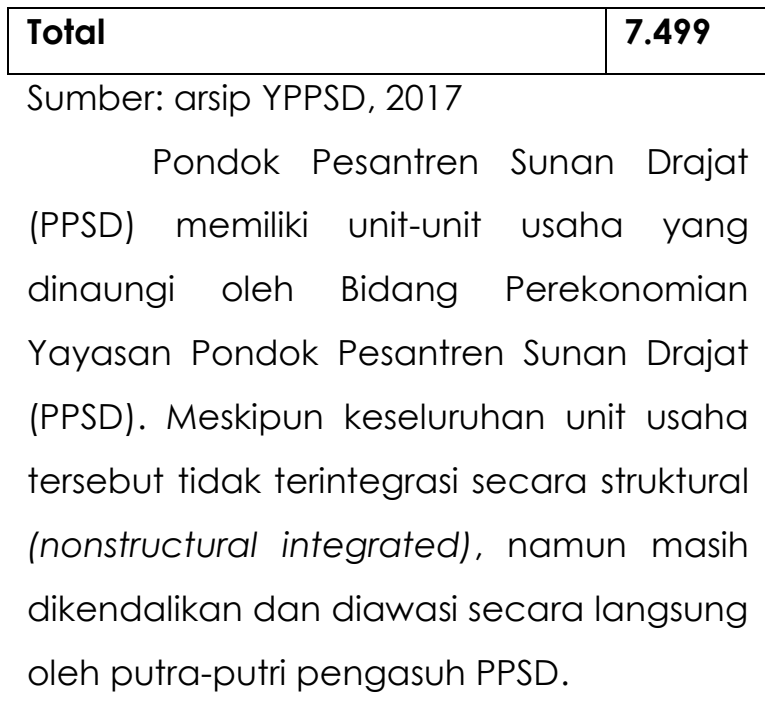

A. Context

Latar belakang adanya unit usaha di PPSD adalah untuk mewujudkan kemandirian finansial sehingga, sehingga visi misi PPSD untuk menyebarkan ajaran Islam kepada masyarakat secara luas dapat tercapai. Upaya ini telah dimulai sejak masa perintisan pesantren. Kiai Abdul Ghofur meneruskan usaha batu gamping milik orang tuanya untuk menghidupi pesantren (wawancara dengan Neng Biyati Ahwarumi tanggal 7 Juni 2017).

Pada tahun 1990-an, bersamaan dengan adanya tren sistem pendidikan pesantren khalafiyah, manajemen pendidikan dan perekonomian di PPSD mulai bertransformasi. Perkembangan pendidikan dan perekonomian pesantren yang kian stabil mengantarkan pada langkah yang lebih luas yakni untuk mendidik santri agar dapat mandiri secara ekonomi. Pemberdayaan ekonomi secara masif mulai dilakukan melalui pencarian bakat minat santri dan pendampingan usaha yang dilakukan oleh yayasan PPSD pada tahun 2003 (wawancara dengan Hilal Sularso tanggal 20 Juni 2017).

Pada dasarnya, pemberdayaan santri adalah bagian dari pendidikan. Sebagaimana dinyatakan oleh Neng Biyati Ahwarumi bahwa core value pesantren ini adalah pendidikan, sehingga semua yang dilakukan pesantren, diantaranya adalah berwirausaha, bertujuan untuk mendukung kontinuitas dan kualitas pendidikan di pesantren (wawancara pada tanggal 7 Juni 2017).

Hal ini dikuatkan melalui penuturan Kiai Abdul Ghofur dalam novel biografinya bahwa "Thoriqoh saya adalah thoriqoh pendidikan" yang artinya beliau telah mendedikasikan seluruh hidupnya untuk memperjuangkan pendidikan. Kepedulian yang tinggi Kiai Abdul Ghofur untuk pendidikan berimplikasi pada kepedulian beliau terhadap hal-hal yang berkaitan dengan pendidikan, diantaranya adalah keberlanjutan pendidikan masyarakat khususnya dalam masalah biaya. Hal ini yang mengantarkan beliau untuk mengakomodasi pendidikan anak-anak kurang mampu dan meringankan biaya pendidikan di pesantren. Kemudian sebagai upaya jangka panjang, beliau menyediakan lapangan kerja untuk masyarakat sekitar dan mendidik santri untuk berwirausaha (Irawan, 2015: 297; 309). Falsafah dan tujuan pemberdayaan ekonomi pesantren tersebut tertulis dalam misi PPSD yang berbunyi "Mengembangkan Jiwa Mandiri pada 
Rahmatika, et al/Jurnal Ekonomi Syariah Teori dan Terapan Vol. 6 No. 10 Oktober 2019: 2052-2061; PERAN PONDOK PESANTREN SUNAN DRAJAT DALAM PEMBERDAYAAN EKONOMI

santri sebagaimana wasiat Sunan Drajat 'Wenehono' (Berilah)".

B. Input

Berikut hal-hal yang dilakukan untuk memulai pemberdayaan:

1. Menjaga dan Menularkan Ghiroh Modal awal dari kegiatan pemberdayaan PPSD adalah ghiroh (semangat) yang kuat. Tanpa adanya hal tersebut, keberadaan dan keberlanjutan usaha pesantren hingga saat ini bisa diragukan karena beliau merintis dari awal (wawancara dengan Neng Biyati Ahwarumi tanggal 7 Juni 2017)

2. Sumber Daya Manusia (SDM) Sosok yang berperan sebagai pihak pemberdaya dalam PPSD ini adalah orang-orang yang telah tertular ghiroh Kiai Abdul Ghofur, sehingga mereka mempelajari ilmu ekonomi dan mengimplementasikannya di pesantren. Selain itu, adanya sasaran pemberdayaan juga merupakan sebuah input pemberdayaan.

3. Aset Bisnis

Aset bisnis yang dimaksud merupakan sarana yang digunakan pesantren dalam memberdayakan ekonomi santri diantaranya berupa tanah, gedung, dana, dan unit-unit usaha pesantren.

4. Dukungan

Dukungan disini dapat diartikan sebagai sebuah lembaga, institusi, perusahaan, kelompok masyarakat, dan sebagainya yang memberikan kontribusi pada kegiatan pemberdayaan ekonomi pesantren baik secara langsung maupun tak langsung.

C. Process

Proses pemberdayaan ekonomi dimulai dengan penyadaran. Langkah penyadaran pesantren dilakukan secara umum sebab berkaitan dengan penyampaian pengetahuan yang perlu difahami oleh semua orang. Pembekalan pengetahuan dasar cara bermuamalah yang sesuai dengan syariat Islam disampaikan secara terpadu dalam proses belajar santri.

Selanjutnya pesantren mendorong santri dan masyarakat untuk memiliki kehendak berwirausaha dan mendorong mereka untuk bergabung dengan unit usaha pesantren agar dapat menerapkan ilmu bermuamalah secara riil. Hal-hal yang sering diungkapkan kepada santri dan masyarakat dalam rangka proses penyadaran ini adalah pentingnya berikhtiar duniawi, memberi, dan bermanfaat untuk umat. Hal ini disampaikan pesantren dengan cara bi'lhāl, bi't-tadwìn, dan bi'l-lisān (memberikan teladan, melalui tulisan, dan melalui lisan).

Langkah kedua dalam proses pemberdayaan adalah pemberian kapasitas kepada pihak yang diberdayakan. Berbeda dengan tahap penyadaran yang dilakukan secara luas, tahap pengkapasitasan ini dilakukan secara eksklusif untuk santri dan masyarakat yang telah bergabung dalam 
unit-unit usaha PPSD. Mayoritas santri yang tergabung adalah santri senior (santri yang sudah lulus tingkat SLTA). Hal ini disebabkan kegiatan mereka lebih longgar dibandingkan santri junior (santri yang duduk di tingkat SLTP dan SLTA) yang berkewajiban untuk sekolah dan mengikuti kurikulum pesantren sepanjang hari.

Tidak ada paksaan bagi santri untuk bekerja di unit usaha pesantren, sehingga proses pengkapasitasan ini terlihat seperti kegiatan ekstrakurikuler yang terbuka untuk siapa saja. Untuk bergabung dalam unit usaha pesantren terdapat prosedur rekrutmen yang bervariatif di tiap-tiap unit usaha. Terdapat prosedur rekrutmen formal dan non formal. Hal itu berbeda-beda berdasarkan kebijakan masing-masing unit usaha. Namun menurut Gus Ahmad Iwan Zunaih, hal itu juga dipengaruhi oleh niat utama santri melamar kerja (wawancara pada tanggal 21 Juni 2017).

Pada tahap ini proses pengkapasitasan santri dan masyarakat yang tergabung di unit usaha pesantren secara riil dimulai. Terdapat beberapa pola pelatihan, diantaranya adalah (1) dilakukan secara intensif. Hal ini biasanya terjadi pada santri yang belum memiliki pengalaman ataupun skill tertentu. Metode pelatihan dapat dilakukan melalui pendampingan, pengawasan, pengadaan seminar, dan sebagainya. Pola jenis ini biasa ditemukan di unit usaha
Persada TV, Toserba, Toko BukU, dan sebagainya.

(2) Tidak terdapat pelatihan skill. Pola kedua ini bisa disebabkan dua hal. Pertama, karena santri atau masyarakat telah memiliki keahlian yang dibutuhkan di unit usaha tersebut, seperti di unit usaha konveksi sebab rekrutmen pegawai di unit usaha tersebut mengharuskan adanya kemampuan menjahit. Kedua, karena pekerjaan yang dilakukan cukup mudah sehingga hanya perlu diarahkan, seperti yang terjadi pada karyawan di perusahaan manufaktur pesantren.

Selain pelatihan teknis, santri dan masyarakat juga diajarkan nilai-nilai Islami dalam keseharian kerjanya. Namun nilainilai ini bersifat universal sehingga nampak seperti bukan suatu tindakan yang besar. Sebagai contoh adalah kebijakan yang diterapkan di PT. SDL. Masyarakat dilarang berjudi, mium-minuman keras, bertindak asusila, dan sebagainya. Hal-hal yang terlihat kecil namun bersifat fundamental tersebut berimbas pada pembentukan karakter yang baik. Terlebih ada atmosfir religius pesantren yang memaksa mereka untuk punya rasa malu dalam melakukan hal-hal yang bersifat negatif.

Contoh-contoh lain mengenai penanaman nilai-nilai Islam di unit usaha pesantren juga membahas tentang etika, seperti tidak diperbolehkannya menggunakan pengenyal pentol, pemanis buatan, pengambilan laba terlalu tinggi, dan sebagainya. 
Pendayaan yang dilakukan tiaptiap unit usaha bervariatif yakni pemberian gaji, pemberian wewenang dalam bentuk jabatan atau amanah yang lain, bantuan jejaring seperti menjadi agen, dan pemberian fasilitas berupa mes, makan, dan kitab yang dapat menunjang kebutuhan hidup dan pendidikan santri dan masyarakat.

D. Product

Output yang dihasilkan dari program pemberdayaan pesantren ini adalah (1) dalam hal bina manusia adalah penguatan karakter santri pegawai yang terbentuk menjadi pribadi yang tangguh, bertanggung jawab, dan mulittalented. Masyarakat pegawai juga dapat mengembangkan dan mendayagunakan kemampuan yang dimiliki. Di samping itu, bekerja di unit usaha pesantren juga bisa menaikkan strata sosial di tengah masyarakat.

(2) Dalam hal bina usaha terdapat penguatan ekonomi. Terdapat perbedaan kemampuan ekonomi sebelum dan sesudah masyarakat bergabung dengan unit usaha pesantren sebab unit usaha pesantren ini telah menjadi tempat mata pencaharian mereka. Masyarakat menjadi lebih mampu memenuhi kebutuhan keluarga mereka. Adapun bagi santri, kondisi perekonomiannya setelah bergabung dengan unit usaha pesantren bertransformasi dari yang awalnya bergantung pada orang tua menjadi mandiri finansial.
(3) Dalam hal bina lingkungan terdapat penguatan lingkungan fisik dan sosial. Lingkungan fisik diwujudkan dari adanya unit usaha yang menyuplai kebutuhan unit usaha lainnya sehingga keberlanjutan usaha dapat terjamin. Lingkungan sosial atau jejaring yang ada di pesantren juga telah mendukung iklim wirausaha. Budaya saling membantu juga tumbuh di antara para pegawai. Adapun jaringan usaha antara pesantren dan alumni santri masih dalam tahap pembangunan melalui Koppontren Sunan Drajat.

(4) Dalam hal bina kelembagaan terdapat penguatan sistem pemberdayaan. Proses panjang pemberdayaan berdampak pada perbaikan-perbaikan sistem pemberdayaan ekonomi pesantren sehingga memiliki manajemen yang lebih paripurna dibandingkan sebelumnya. Dampak jangka panjang atau outcome dari pemberdayaan ini adalah terbentuknya alumni santri yang faham ilmu agama dan berjiwa entrepeneur sehingga ia bisa menjadi wirausahawan yang mampu mengimplementasikan nilainilai Islami secara kaffah. Kemudian hal ini juga berdampak pada peningkatan kesejahteraan masyarakat. Bila terjadi secara terus menerus, dampak yang dihasilkan oleh pemberdayaan ini sesuai dengan apa yang diharapkan oleh Pengasuh PPSD dalam mengawali pemberdayaannya, yakni peningkatan taraf hidup masyarakat agar dapat 
Rahmatika, et al/Jurnal Ekonomi Syariah Teori dan Terapan Vol. 6 No. 10 Oktober 2019: 2052-2061; PERAN PONDOK PESANTREN SUNAN DRAJAT DALAM PEMBERDAYAAN EKONOMI

memberikan pendidikan yang layak pada generasi penerus bangsa.

Dari kegiatan pemberdayaan yang dilakukan, keluaran pesantren ini diharapkan bisa survive dalam kehidupan perekonomiannya sehingga mereka dapat meraih, mengamalkan, dan mensyiarkan ilmunya tanpa mengkhawatirkan persoalan finansial. Sebagaimana dijelaskan dalam kitab ta lim muta allim bahwa biaya merupakan salah satu persyaratan untuk mencari ilmu.

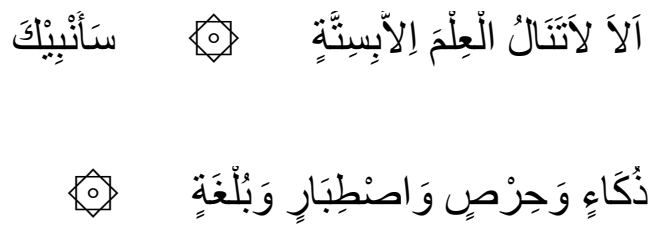

Alā lā tanālu'l-ilma illā bi sittatin. Sa-unbika án majmūihā bibayānin. Zuvkā-in wa ḥirșin wașțibārin wa bulgotin. Wa irsyādu ustāẓin wa țūli zamānin.

Artinya: "Ingatlah, tidak akan kalian mendapatkan ilmu yang manfaat kecuali dengan enam syarat, yaitu cerdas, semangat, sabar, biaya, petunjuk guru, dan waktu yang lama"(Az Zarnuji, t.t. : 15). Keenam elemen tersebut telah diajarkan cara untuk meraihnya di pendidikan pesantren.

Terdapat pula pemberdayaan ekonomi tak langsung yang terjadi karena akibat aktifitas pesantren, diantaranya adalah (1) keberdayaan ekonomi santri karyawan. Sebagaimana dijelaskan sebelumnya bahwa keuntungan dari manajemen $C$ dialokasikan untuk santri karyawan yang telah membangun dan memperbaiki bangunan fisik pesantren. Seluruh biaya hidup dan biaya pendidikan santri karyawan ditanggung oleh pesantren.

(2) Efek domino dari aktifitas unit usaha, diantaranya adalah masyarakat yang menitipkan produk makanan atau lainnya di unit usaha pesantren. (3) Penyediaan stan pada saat Haul Akbar pesantren. Pada momen tersebut masyarakat dan santri, baik santri pegawai maupun nonpegawai bebas berkreasi membuka usaha di area pondok putra yang sekitar 13 hektar tersebut.

Iklim kewirausahaan juga menyentuh santri yang masih berada di bangkU SLTP dan SLTA dengan membuka stan-stan yang menyasar anggota sekolah masing-masing. Stan tersebut biasa didesain sedemikian rupa agar para anggota juga nyaman untuk berinteraksi, rapat, atau bahkan reoni. Hal yang serupa juga terjadi pada para alumni. Setiap alumni dari wilayah Lamongan, Gresik, Tuban, Bojonegoro, dan lainnya juga membuat stan di Haul Akbar PPSD.

\section{v. SIMPULAN}

Hasil penelitian mengenai model pemberdayaan ekonomi di Pondok Pesantren Sunan Drajat berdasarkan analisis evaluasi CIPP menunjukkan bahwa sambil memenuhi kebutuhan operasional, pesantren mampu memenuhi keinginannya untuk mendidik jiwa kemandirian santri dan membuka lapangan kerja. Upaya tersebut dipandu oleh desain manajemen yang selalu 
Rahmatika, et al/Jurnal Ekonomi Syariah Teori dan Terapan Vol. 6 No. 10 Oktober 2019: 2052-2061; PERAN PONDOK PESANTREN SUNAN DRAJAT DALAM PEMBERDAYAAN EKONOMI

dimodifikasi sesuai kebutuhan, sehingga proses pemberdayaan mampu memberikan dampak positif pada bidang biina manusia, usaha, lingkungan, dan kelembagaan.

\section{DAFTAR PUSTAKA}

Ahwarumi, Biyati. 2011. Perencanaan Strategis Sistem Informasi Pondok Pesantren Sunan Drajat dalam Rangka Pengendalian Internal Organisasi. Skripsi tidak diterbitkan. Malang: Fakultas Ekonomi UIN Malang.

Fauroni, R Lukman. 2011. Model Pemberdayaan Ekonomi Ala Pesantren Al-Ittifaq Rancabali Kab. Bandung. Inferensi, Jurnal Penelitian Sosial Keagamaan. Vol. 5, No. 1 (6):1-17.

Geertz, Clifford. 2014. The Religion of Java. Terjemahan oleh Aswab Mahasin dan Bur Rasuanto. Depok: Komunitas Bambu.

Jamaluddin, Muhammad. 2012. Metamorfosis Pesantren di Era Globalisasi. Jurnal Karsa, Vol. 20, No. 1: 127-139.

Kudhori, Moh. Amin. 2013. Pemberdayaan Ekonomi Umat Islam Dalam Prespektif Al-Quran. Skripsi tidak diterbitkan. Semarang: Fakultas Ushuluddin Institut Agama Islam Negeri Walisongo.

Mardikanto, Totok. 2010. Konsep-Konsep Pemberdayaan Masyarakat. Surakarta: UNS Press.
Mursyid. 2011. Dinamika Pesantren dalam Prespektif Ekonomi. Jurnal Millah, Vol. XI, No. 1 (8): 171-187.

Muslim, Azis. 2014. Model Pemberdayaan Ekonomi Masyarakat Miskin Perkotaan Berbasis Tanggung Jawab Sosial Masjid. Disertasi tidak diterbitkan. Surakarta: Pascasarjana Penyuluhan Pembangunan Universitas Negeri Surakarta.

Sakai, Minakao and M. Falikul Isbah. 2014. Limits to Religious Diversity Practice in Indonesia: Case Studies from Religious Philanthropic Institutions and Traditional Islamic Schools. Asian Journal of Social Science, 42: 722-746.

Siswanto NS. 2008. Model Pengembangan Ekonomi Pondok Pesantren. Jurnal Penelitian Pendidikan Agama dan Keagamaan, Vol. 6, No. 3 (7): 1836.

Sugiyono. 2015. Metode Penelitian Kuantitatif, Kualitatif, dan R\&D. Bandung: Penerbit Alfabeta.

Wrihatnolo, Randi R., dan Riant Nugroho Dwiidjowijoto. 2007. Manajemen Pemberdayaan: Sebuah Pengantar dan Panduan untuk Pemberdayaan Masyarakat. Jakarta: PT. Elex Media Komputindo.

Zarnuji, Burhan al-Islam al-. t.t. Talim alMuta'allim (dalam syarh syaikh Ibrahim bin Isma'il). Surabaya: Nur al-Huda. 